\title{
Growth performance, nitrogen balance and urinary purine derivatives in growing-furring mink (Mustela vison) fed bacterial protein produced from natural gas
}

\author{
Ø. Ahlstrøm ${ }^{1,4}$, A.-H. Tauson ${ }^{2,3}$, A.L. Frydendahl Hellwing ${ }^{2}$, \\ L.T. Mydland ${ }^{3}$ and A. Skrede ${ }^{1,3}$ \\ ${ }^{1}$ Department of Animal and Aquacultural Sciences, Norwegian University of Life Sciences \\ P.O. Box 5003, N-1432 As, Norway \\ ${ }^{2}$ Department of Animal and Veterinary Basic Sciences, \\ The Royal Veterinary and Agricultural University \\ Grønnegaardsvej 3, DK-1870 Frederiksberg C, Denmark \\ ${ }^{3}$ Aquaculture Protein Centre, Centre of Excellence \\ P.O. Box 5003, N-1432 As, Norway
}

(Received 3 March 2006; revised version 28 April 2006; accepted 5 July 2006)

\begin{abstract}
A bacterial protein meal (BPM), containing $70 \%$ crude protein and produced on natural gas, was evaluated versus fish meal as protein source for mink in the growing-furring period (June 29 - November 26). BPM, rich in nucleic acids, accounted for 0 (control), 20 and $40 \%$ of dietary crude protein corresponding to 0,4 and $8 \%$ of the wet diets, respectively. Each diet was given to 48 animals, 24 males and 24 females. The inclusion of BPM tended to reduce feed intake and body weight gain during the first half of the experimental period, but this was compensated for during the last part of the experiment, except for males on the 8\% BPM diet. Balance experiments carried out with 18 and 28 weeks old males, revealed similar digestibility of main nutrients except for fat that were reduced with BPM inclusion. N-retentions were similar for the dietary groups. Daily excretion of urine was lower with the $8 \%$ BPM diet than with the other diets. Excretion of urinary purine derivatives (allantoin, xanthine), decreased or was not consistently affected (hypoxanthine, uric acid) by the dietary level of BPM, indicating that nucleic acids from BPM were utilized in vivo. The skin characteristics and fur quality were not affected by diet, except for shorter hair length with inclusion of BPM. In conclusion, the experiment showed that BPM can account for $40 \%$ of dietary protein in growing-furring mink without negative effects on $\mathrm{N}$ metabolism, body weight gain or fur quality.
\end{abstract}

KEY WORDS: bacterial protein, growth, purine derivatives, mink, fur

\footnotetext{
${ }^{4}$ Corresponding author: e-mail: oystein.ahlstrom@umb.no
} 


\section{INTRODUCTION}

The mink (Mustela vison) is by nature a carnivorous species with a high protein requirement (NRC, 1982; Hansen et al., 1991), and diets used in commercial mink production characteristically contain high levels of animal protein. In the search for alternative protein sources, use of different single cell proteins in diets for mink have previously been studied (Skrede, 1976), but there is a paucity of recent information on use of single cell proteins in intensive mink production. Bacterial protein meal (BPM) is a bacterial protein source produced by an aerobe bacterial culture (Methylococcus capsulatus Bath, Ralstonia sp., Aneurinibacillus sp., Brevibacillus agri), using natural gas with $99 \%$ methane as source of carbon and energy, and in addition, ammonia and mineral salts for fermentation and protein synthesis (Skrede et al., 1998). The final spray-dried BPM is a reddish/brownish meal containing approximately, \%: dry matter (DM) 95, crude protein (CP) 70, lipids 10 and ash 7. The methane-utilizing bacteria used for production of BPM have an amino acid composition similar to that of fish meal, except for a lower content of lysine and higher contents of tryptophan and threonine (Skrede et al., 1998). Digestibility experiments with BPM for different monogastric species typically show high digestibility of lysine and arginine, but low digestibility of cysteine (Skrede et al., 1998). Growth performance experiments with BPM in diets for pigs (Øverland et al., 2001, 2004, 2006), blue foxes (Skrede and Ahlstrøm, 2002), chickens (Skrede et al., 2003), and Atlantic salmon (Storebakken et al., 2004; Berge et al., 2005) have shown that substantial amounts of BPM can be fed without any growth impairment. The BPM has been studied in nitrogen and energy balance experiments with growing mink, and it was concluded that BPM may constitute up to $40 \%$ of dietary crude protein without negative effects on protein or energy metabolism (Hellwing et al., 2005). However, limited information exists on effects of different inclusion levels on long-term growth performance and fur characteristics in mink. Furthermore, the effects of the inherent nucleic acids in BPM remain to be elucidated. The BPM contains about 7.3\% RNA and $2.2 \%$ DNA (Skrede et al., 1998), and replacement of conventional protein sources in mink diets with BPM would cause an increase in dietary nucleic acids.

The present study was conducted to study the effect of graded levels of BPM in mink diets on growth performance and fur characteristics, and secondly to measure the effects of dietary BPM on nitrogen balance and urinary excretion of purine derivatives. 


\section{MATERIAL AND METHODS}

\section{Animals and diets}

Experimental animals were mink (Mustela vison) of the standard brown genotype. The growth performance experiment started June 29, when the animals were 2 months old, and ended at pelting November 26. The experiment comprised three groups of 24 males and 24 females each. The groups were balanced according to age and initial body weight, and littermates within the same sex were allocated to different groups. Two animals, one male and one female, were housed in each cage. The cage size was $78 \mathrm{~cm} \times 38 \mathrm{~cm} \times 30 \mathrm{~cm}$ (height) and each cage was equipped with an outside nestbox. The animals were fed once a day ad libitum, and daily feed consumption was recorded on a group basis as feed offered minus feed rejected. Individual body weights were recorded monthly. The animals were pelted in accordance with common farming practice. Skin length, from tip of nose to base of tail, and skin weight were measured after fleshing and drying.

Table 1. Ingredient composition, chemical analyses, metabolizable energy (ME) content and ME distribution of the experimental diets

\begin{tabular}{|c|c|c|c|}
\hline \multirow{2}{*}{ Item } & \multirow{2}{*}{ Control } & \multicolumn{2}{|c|}{ BPM, \% } \\
\hline & & 4 & 8 \\
\hline \multicolumn{4}{|l|}{ Ingredients, $\%$} \\
\hline fish meal ${ }^{1}$ & 12.0 & 8.0 & 4.0 \\
\hline bacterial protein meal (BPM) & 0.0 & 4.0 & 8.0 \\
\hline cod scraps & 15.0 & 15.0 & 15.0 \\
\hline slaughterhouse by-products & 12.0 & 12.0 & 12.0 \\
\hline soyabean oil & 4.0 & 4.0 & 4.0 \\
\hline extruded wheat & 14.0 & 14.0 & 14.0 \\
\hline expanded wheat/oats & 4.0 & 4.0 & 4.0 \\
\hline vitamin/mineral $\mathrm{mix}^{2}$ & 0.1 & 0.1 & 0.1 \\
\hline water & 39.0 & 39.0 & 39.0 \\
\hline \multicolumn{4}{|l|}{ Chemical analyses, $\%$} \\
\hline dry matter (DM) & 37.3 & 38.6 & 37.9 \\
\hline crude protein & 14.0 & 14.2 & 13.3 \\
\hline crude fat & 7.2 & 6.8 & 7.1 \\
\hline carbohydrates (by difference) & 13.3 & 15.1 & 15.4 \\
\hline ash & 2.8 & 2.5 & 2.1 \\
\hline ME content, $\mathrm{MJ} / \mathrm{kg}$ feed & 6.89 & 7.05 & 6.89 \\
\hline $\mathrm{MJ} / \mathrm{kg} \mathrm{DM}$ & 18.57 & 18.26 & 18.18 \\
\hline Protein, $\%$ of $\mathrm{ME}$ & 31.4 & 32.7 & 31.2 \\
\hline Fat, $\%$ of ME & 39.7 & 35.1 & 36.3 \\
\hline Carbohydrates, $\%$ of ME & 28.9 & 32.2 & 32.4 \\
\hline
\end{tabular}

${ }^{1}$ Norseamink, Norsildmel, Bergen (Norway); ${ }^{2}$ Norsk Mineralnæring, Hønefoss, Norway. Ingredients per kg, IU: vit. A, 2000 000, vit. D3, 200000 IU; mg: vit. E 50 000, vit. B, 15 000, vit. $\mathrm{B}_{2} 3000$, vit. $\mathrm{B}_{6} 3000$, vit. $\mathrm{B}_{12} 20$, pantothenic acid 3000; niacin 5000 , biotin 30, folic acid $300, \mathrm{Fe}$ (amino acid-chelated) $20000, \mathrm{Zn}$ oxide $7500, \mathrm{Mn}$ oxide 15000 and $\mathrm{Cu}$ sulphate 1250

3 factors used for calculating metabolizable energy (kJ per g digestible nutrient): crude protein, 18.8; fat, 39.7; carbohydrates, 17.6 (Hansen et al., 1991) 
Length of guard fur and underfur was measured as outlined by Reiten (1977). Fur quality gradings were carried out on dried, undressed skins by experienced personnel at the research station of the Norwegian University of Life Sciences. Fur colour was graded on a scale from 1 (lightest) to 10 (darkest), and purity from 1 (poorest) to 5 (best). Fur density, hair quality and total impression were rated from 1 (poorest) to 10 (best).

Diet composition is given in Table 1 . The diets were formulated to contain adequate levels of nutrients required by growing-furring mink (NRC, 1982). Chemical analyses of the diets and respective digestibility values obtained in 18 weeks old male kits in the $\mathrm{N}$-experiment balance experiment (see below) and ME coefficients (Hansen et al., 1991; see Table 1) were applied to determine ME content of the diets. Fish meal provided $60 \%$ of total crude protein (CP) in the control diet and in the other diets bacterial protein meal (BPM) replaced $1 / 3$ and $2 / 3$ of the fish meal on the basis of crude protein content, thus accounting for approximately 20 and $40 \%$ of digestible protein, respectively. All other ingredients were used at constant levels. Feed was produced twice a week and kept in a refrigerator at $+3^{\circ} \mathrm{C}$ until feeding.

\section{$N$-balance experiments}

Two N-balance experiments were carried out with six 18-weeks old (August 21 September 1) and 28-weeks old (October 16-25) male kits from the respective treatment groups, using the same animals in both experiments. The adaptation to the new cage environment lasted seven days and the following faecal and urine collection period lasted four days. The animals were kept in metabolism cages constructed for separate collection of faeces and urine, in principle as described by Jørgensen and Glem-Hansen (1973). Faeces and urine were collected quantitatively daily and kept frozen pending analyses. To avoid ammonia evaporation from the urine, $20 \mathrm{ml}$ sulphuric acid $(5 \%$ solution) was added to the urine collection bottles, and the urine collection trays were sprayed with citric acid ( $20 \%$ solution) once per day. In the N-balance calculations, retained $\mathrm{N}$ was determined as ingested $\mathrm{N}$ - (faecal $\mathrm{N}$ +urinary $\mathrm{N})$.

\section{Chemical analyses}

Feed and faecal samples were analysed for dry matter (EC, 1971b), ash (EC, 1971a), crude protein (EC, 1993) and fat (EC, 1998). Starch was analysed according to McCleary et al. (1984). Carbohydrate contents were calculated by difference. In the N-balance experiment, urine was analysed for nitrogen and nucleic acid derivatives excreted in urine (allantoin, uric acid, hypoxanthine, xanthine) plus creatinine were analysed by HPLC (Hewlett Packard HP 1100, fitted with a LiChrospher 100-RP18e column) as described by Thode (1999). Urine samples of 
$5 \mathrm{ml}$ were mixed with $2.5 \mathrm{ml} \mathrm{NaOH}$ (4\% solution), micro-filtrated $(0.45 \mu \mathrm{m})$ and cooled on ice followed by a proper dilution prior to injection. A $10 \mathrm{mM} \mathrm{KH}_{2} \mathrm{PO}_{4}$ buffer, $\mathrm{pH} 4$ was used as the mobile phase, and the eluents were detected by UVabsorbance at $218 \mathrm{~nm}$. Data were analysed against external standards using the Hewlett-Packard HP ChemStation Software. Kit No. A11A0641-ABX produced by Pentra, France was used for analysing urea in urine.

\section{Statistical analyses}

Analysis of variance was applied by the GLM procedure of SAS (SAS Institute, 2002). The 1s-means/pdiff statement was used to test differences between treatments. For body weight gain in the production experiment, effects of diet, sex and interaction were tested in the model:

$$
\mathrm{Y}_{\mathrm{ik}}=\mu+\alpha_{\mathrm{i}}+\beta_{\mathrm{j}}+\alpha_{\mathrm{i}} \beta_{\mathrm{j}}+\varepsilon_{\mathrm{ik}}
$$

$\mathrm{Y}_{\mathrm{ik}}=\mathrm{ik}$ th observation

$\mu=$ general mean

$\alpha_{i}=$ fixed effect of diet

$\beta_{\mathrm{j}}=$ fixed effect of sex

$\alpha_{\mathrm{i}} \beta_{\mathrm{j}}=$ effect of interaction diet*sex

$\varepsilon_{\mathrm{ik}}=$ random effect

In the N-balance experiment effects of diet and age were tested. Interaction effects were not significant $(\mathrm{P}>0.05)$ and were therefore not included in the model:

$$
\mathrm{Y}_{\mathrm{ijk}}=\mu+\alpha_{\mathrm{i}}+\beta_{\mathrm{j}}+\varepsilon_{\mathrm{ijk}}
$$

$\mathrm{Y}_{\mathrm{ijk}}=\mathrm{ijk}$ th observation

$\mu \quad$ general mean

$\alpha_{i}=$ fixed effect of diet

$\beta_{\mathrm{j}} \quad$ = fixed effect of age

$\varepsilon_{\mathrm{ijk}}=$ random effect

In the skin and fur data, the effect of diet within each sex was tested for using the model:

$\mathrm{Y}_{\mathrm{ik}}=\mathrm{ik}$ th observation

$$
\mathrm{Y}_{\mathrm{ik}}=\mu+\alpha_{\mathrm{i}}+\varepsilon_{\mathrm{i}}
$$

$\mu=$ general mean

$\alpha_{i} \quad=$ fixed effect of diet

$\varepsilon_{\mathrm{ik}}=$ random effect 


\section{RESULTS}

\section{Feed intake and growth performance}

During the first two months of the experiment, the mean feed intake decreased with increasing BPM levels in the diets, but in the total experimental period there were minor differences in average feed and ME intakes between control animals and animals fed the 4\% BPM diets, but slightly lower average levels among animals fed the $8 \%$ BPM diet (Table 2). No clinical disorders were

Table 2. Mean feed intake, ME intake, and feed conversion in males and females

\begin{tabular}{lccc}
\hline & Control & \multicolumn{2}{c}{ Diet with BPM } \\
\cline { 3 - 4 } & diet & $4 \%$ & $8 \%$ \\
\hline Feed intake, g/day & 236 & 235 & 230 \\
ME intake, MJ/day & 1.63 & 1.66 & 1.59 \\
Feed conversion, kJ ME/g BW gain & 127 & 131 & 132 \\
\hline
\end{tabular}

recorded and no animals died during the experiment. During the first two months of the experiment, body weights of male kits were lower with increasing levels of BPM (Table 3; Figure 1). Due to increased growth rate during the remaining part of the experiment, there was no difference in male body weights between the control and 4\% BPM groups later in the experimental period. Male kits fed the $8 \%$ BPM diet were significantly lighter than the control and 4\% BPM males throughout the experiment until pelting in November and showed a significantly lower total weight gain. For the female kits there were no significant differences in body weights, with the exception that animals fed 8\% BPM had lower body

Table 3. Mean body weight gain $(\mathrm{g})$ in the production experiment $(\mathrm{n}=48)$ and effect of diet, sex and diet $\times$ sex. SEM $=$ standard error of the mean

\begin{tabular}{|c|c|c|c|c|c|c|c|c|c|}
\hline & \multicolumn{3}{|c|}{ Diet } & \multicolumn{2}{|c|}{ Sex } & \multirow[b]{2}{*}{ SEM } & \multicolumn{3}{|c|}{ P-values } \\
\hline & control & $\begin{array}{c}4 \% \\
\text { BPM }\end{array}$ & $\begin{array}{c}8 \% \\
\text { BPM }\end{array}$ & male & female & & diet & $\operatorname{sex}$ & $\operatorname{diet} \times \operatorname{sex}$ \\
\hline June 29-Aug 7 & $805^{\mathrm{a}}$ & $747^{b}$ & $689^{c}$ & 944 & 550 & 19.3 & $<0.0001$ & $<0.0001$ & 0.03 \\
\hline Aug 7-Sept 5 & $480^{\mathrm{a}}$ & $408^{b}$ & $329^{c}$ & 530 & 282 & 18.4 & $<0.0001$ & $<0.0001$ & 0.14 \\
\hline Sept 5-Oct 6 & $427^{b}$ & $583^{\mathrm{a}}$ & $613^{\mathrm{a}}$ & 698 & 385 & 21.1 & $<0.0001$ & $<0.0001$ & 0.18 \\
\hline Oct 6-Nov 26 & 197 & 148 & 158 & 239 & 96 & 17.8 & 0.11 & $<0.0001$ & 0.32 \\
\hline June $29-$ Nov 26 & $1918^{\mathrm{a}}$ & $1886^{\mathrm{a}}$ & $1783^{\mathrm{b}}$ & 2411 & 1315 & 39.5 & 0.045 & $<0.0001$ & 0.017 \\
\hline
\end{tabular}

different letters within diet and within age denote significant differences $(\mathrm{P}<0.05)$ 


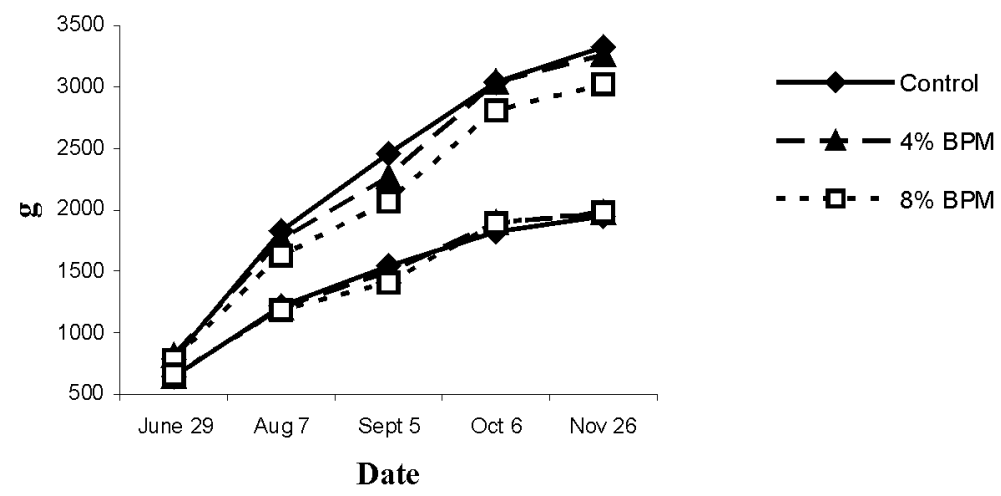

Figure 1. Growth rate in males (upper curves) and females (lower curves) in the production experiment

weight at the September weighing compared with animals fed the control diet, and there was no difference in total weight gain. The feed intake and feed conversion rates were similar for all diets (Table 2).

\section{Nutrient digestibility and $N$ balance}

Body weight gain was not significantly different among diets in any of the balance periods, but it was significantly lower at 28 weeks of age than at 18 weeks of age (Table 4). Furthermore, when kits were 18 weeks of age the $8 \%$ BPM diet caused lower ME intakes, as well as lower levels of ingested N, digested $\mathrm{N}$ and urinary $\mathrm{N}$ compared with the other diets, but at 28 weeks there were no significant differences. The $\mathrm{N}$ digestibility was not significantly different among diets, but the digestibility of other main nutrients, especially for fat, decreased with increasing dietary level of BPM. Digestibility of the main nutrients, except fat, was higher in 18 weeks old animals than in 28 weeks old, but the numerical difference was minor (Table 4). The ME intake per $\mathrm{kg} \mathrm{BW}^{0.75}$ was lower at 28 weeks than at 18 weeks. The data on $\mathrm{N}$ retention revealed an effect of age, $\mathrm{N}$ retention being lowest among 28 weeks old kits, but due to great individual variability there was no significant effect of diet.

\section{Urinary excretion of purine derivatives}

Total urine excretion was significantly lower in animals given the 8\% BPM diet than in animals fed the other diets (Table 5), while feeding of $4 \%$ BPM had 
Table 4. Mean values in N-balance experiments with males. Body weights (BW), BW gain, ME intake, apparent digestibilities, N-balance values, SEM and P-values ( $\mathrm{n}=6$ )

\begin{tabular}{|c|c|c|c|c|c|c|c|c|}
\hline & \multicolumn{3}{|c|}{ Diet } & \multicolumn{2}{|c|}{ Age, weeks } & \multirow{2}{*}{$\begin{array}{c}\text { - Pooled } \\
\text { SEM }\end{array}$} & \multicolumn{2}{|c|}{ P-value } \\
\hline & control & $\begin{array}{c}4 \% \\
\text { BPM }\end{array}$ & $\begin{array}{c}8 \% \\
\text { BPM }\end{array}$ & 18 & 28 & & diet & age \\
\hline $\mathrm{BW}, \operatorname{start}^{1}, \mathrm{~g}$ & 2645 & 2720 & 2391 & 2118 & 3053 & 100 & 0.30 & $<0.001$ \\
\hline $\mathrm{BW}$, end $^{1}, \mathrm{~g}$ & 2723 & 2792 & 2459 & 2202 & 3114 & 102 & 0.26 & $<0.001$ \\
\hline BW gain, $g / d$ & 19.4 & 18.0 & 17.0 & 21.1 & 15.2 & 2.2 & 0.78 & 0.003 \\
\hline ME intake, $\mathrm{kJ} / \mathrm{kg}^{0.75} / \mathrm{d}$ & 996 & 991 & 981 & $1137^{\mathrm{a}}$ & $841^{\mathrm{b}}$ & 35 & 0.98 & 0.001 \\
\hline \multicolumn{9}{|l|}{ Digestibilitiy, \% } \\
\hline nitrogen & 86.4 & 86.3 & 86.0 & $86.7^{\mathrm{a}}$ & $85.8^{\mathrm{b}}$ & 0.4 & 0.65 & 0.02 \\
\hline crude fat & $95.5^{\mathrm{a}}$ & $91.4^{\mathrm{b}}$ & $88.5^{\mathrm{c}}$ & $89.5^{\mathrm{b}}$ & $94.0^{\mathrm{a}}$ & 0.8 & $<0.001$ & 0.001 \\
\hline starch & 99.0 & 99.0 & 98.6 & $99.1^{\mathrm{a}}$ & $98.7^{\mathrm{b}}$ & 0.1 & 0.101 & 0.005 \\
\hline carbohydrates & $85.3^{\mathrm{ab}}$ & $85.6^{\mathrm{a}}$ & $82.6^{\mathrm{b}}$ & $85.7^{\mathrm{a}}$ & $83.3^{\mathrm{b}}$ & 0.4 & 0.001 & 0.001 \\
\hline \multicolumn{9}{|l|}{$N$-balance, $g / d$} \\
\hline ingested $\mathrm{N}$ & 6.45 & 6.43 & 6.19 & $6.48^{\mathrm{a}}$ & $6.22^{\mathrm{b}}$ & 0.13 & 0.39 & 0.001 \\
\hline faecal N & 0.88 & 0.88 & 0.87 & 0.86 & 0.88 & 0.03 & 0.90 & 0.40 \\
\hline digested $\mathrm{N}$ & 5.58 & 5.54 & 5.32 & 5.62 & 5.34 & 0.12 & 0.34 & 0.08 \\
\hline urinary $\mathrm{N}$ & 4.43 & 4.56 & 4.08 & 4.37 & 4.34 & 0.13 & 0.09 & 0.85 \\
\hline retained $\mathrm{N}$ & 1.12 & 1.09 & 1.24 & $1.30^{\mathrm{a}}$ & $1.00^{\mathrm{b}}$ & 0.12 & 0.74 & 0.05 \\
\hline retained $\mathrm{N} /$ digested $\mathrm{N}, \%$ & 20.1 & 19.4 & 23.3 & 23.2 & 18.6 & 2.34 & 0.51 & 0.12 \\
\hline
\end{tabular}

different letters within diet and within age denote significant differences $(\mathrm{P}<0.05)$

${ }^{1}$ collection period $=$ four days

Table 5. Mean effects of dietary BPM and age on daily urine volume $(\mathrm{ml} / \mathrm{d})$ and urinary concentration (per L urine) and excretion (per d) of urea, purine derivatives (allantoin, uric acid, xanthine and hypoxanthine) and creatinine in N-balance experiments. SEM=standard error of the mean

\begin{tabular}{|c|c|c|c|c|c|c|c|c|}
\hline & \multicolumn{3}{|c|}{ Diet } & \multicolumn{2}{|c|}{ Age, weeks } & \multirow{2}{*}{$\begin{array}{l}\text { Pooled } \\
\text { SEM }\end{array}$} & \multicolumn{2}{|c|}{ P-value } \\
\hline & control & $\begin{array}{c}4 \% \\
\text { BPM }\end{array}$ & $\begin{array}{c}8 \% \\
\text { BPM }\end{array}$ & 18 & 28 & & diet & age \\
\hline $\begin{array}{l}\text { Urine excretion, } \\
\mathrm{ml} / \mathrm{d}\end{array}$ & $124^{\mathrm{a}}$ & $125^{\mathrm{a}}$ & $100^{\mathrm{b}}$ & 117 & 116 & 4.5 & 0.002 & 0.76 \\
\hline Urea, $\mathrm{mmol} / \mathrm{L}$ & $1243^{a}$ & $1260^{\mathrm{a}}$ & $1455^{\mathrm{b}}$ & 1289 & 1350 & 36 & 0.003 & 0.29 \\
\hline Urea, $\mathrm{mmol} / \mathrm{d}$ & 606 & 625 & 585 & 595 & 614 & 19 & 0.54 & 0.47 \\
\hline Allantoin, mmol/L & $20.9^{\mathrm{a}}$ & $15.0^{\mathrm{b}}$ & $15.0^{\mathrm{b}}$ & $11.8^{\mathrm{b}}$ & $22.1^{\mathrm{a}}$ & 1.5 & $<0.001$ & $<0.001$ \\
\hline Allantoin, mmol/d & $10.0^{\mathrm{a}}$ & $7.4^{\mathrm{b}}$ & $6.2^{\mathrm{b}}$ & $5.7^{\mathrm{b}}$ & $10.0^{\mathrm{a}}$ & 0.6 & 0.001 & 0.001 \\
\hline Uric acid, $\mu \mathrm{mol} / \mathrm{L}$ & 35.8 & 36.7 & 50.4 & $53.6^{\mathrm{a}}$ & $28.3^{\mathrm{b}}$ & 9.3 & 0.15 & 0.04 \\
\hline Uric acid, $\mu \mathrm{mol} / \mathrm{d}$ & 18.5 & 19.2 & 20.2 & $25.9^{\mathrm{a}}$ & $12.7^{\mathrm{b}}$ & 4.7 & 0.97 & 0.03 \\
\hline Xanthine, $\mu \mathrm{mol} / \mathrm{L}$ & 44.2 & 37.1 & 37.1 & $50.3^{\mathrm{a}}$ & $28.6^{\mathrm{b}}$ & 3.2 & 0.27 & 0.001 \\
\hline Xanthine, $\mu \mathrm{mol} / \mathrm{d}$ & $21.7^{\mathrm{a}}$ & $18.6^{\mathrm{ab}}$ & $14.6^{\mathrm{b}}$ & $23.7^{\mathrm{a}}$ & $12.3^{\mathrm{b}}$ & 1.5 & 0.02 & 0.001 \\
\hline $\begin{array}{l}\text { Hypoxanthine, } \\
\mu \mathrm{mol} / \mathrm{L}\end{array}$ & $162^{b}$ & $201^{\mathrm{a}}$ & $205^{\mathrm{a}}$ & $223^{a}$ & $155^{\mathrm{b}}$ & 14.5 & 0.003 & 0.001 \\
\hline $\begin{array}{l}\text { Hypoxanthine, } \\
\mu \mathrm{mol} / \mathrm{d}\end{array}$ & 77.2 & 100.4 & 80.6 & $101.5^{\mathrm{a}}$ & $70.6^{b}$ & 6.5 & 0.06 & 0.001 \\
\hline Creatinine, $\mathrm{mmol} / \mathrm{L}$ & 7.9 & 4.5 & 5.5 & 7.2 & 4.7 & 1.5 & 0.24 & 0.17 \\
\hline Creatinine, $\mathrm{mmol} / \mathrm{d}$ & 3.9 & 2.1 & 2.2 & 3.5 & 2.0 & 0.3 & 0.18 & 0.09 \\
\hline
\end{tabular}

different letters within age or diet denote significant differences $(\mathrm{P}<0.05)$ 
no effect. Urea concentration was highest among animals fed 8\% BPM, but total urea excretion was not affected by diet. Allantoin accounted for the major part of the purine metabolites in urine $(>97 \%)$, and the concentrations of uric acid, xanthine and hypoxanthine were comparably low. Concentrations and total excretion of allantoin were significantly lower among animals fed 4 or $8 \%$ BPM than in animals fed the control diet. The urinary excretion of allantoin was

Table 6. Mean values for skin and fur quality characteristics. SEM=standard error of the mean

\begin{tabular}{|c|c|c|c|c|c|}
\hline & \multirow{2}{*}{$\begin{array}{c}\text { Control } \\
\text { diet }\end{array}$} & \multicolumn{2}{|c|}{ Diets with BPM } & \multirow{2}{*}{$\begin{array}{c}\text { Pooled } \\
\text { SEM }\end{array}$} & \multirow{2}{*}{ P-values } \\
\hline & & $4 \%$ & $8 \%$ & & \\
\hline \multicolumn{6}{|l|}{ Males, $\mathrm{n}=20$} \\
\hline skin length, $\mathrm{cm}$ & 87 & 86 & 85 & 0.9 & 0.21 \\
\hline skin weight, g & 223 & 228 & 222 & 6.9 & 0.85 \\
\hline colour & 5.8 & 6.4 & 5.5 & 0.3 & 0.17 \\
\hline purity & 2.9 & 2.9 & 2.8 & 0.6 & 0.96 \\
\hline guard fur density & 5.4 & 5.7 & 5.7 & 0.2 & 0.49 \\
\hline under-fur density & 4.8 & 5.6 & 5.8 & 0.3 & 0.06 \\
\hline hair quality & 5.4 & 5.8 & 5.6 & 0.2 & 0.49 \\
\hline guard hair length, mm & $24.9^{\mathrm{a}}$ & $24.1^{\mathrm{a}}$ & $22.7^{\mathrm{b}}$ & 0.3 & 0.004 \\
\hline under-fur length, mm & $15.7^{\mathrm{a}}$ & $15.4^{\mathrm{a}}$ & $14.1^{\mathrm{b}}$ & 0.6 & 0.001 \\
\hline total impression & 5.4 & 6.0 & 5.9 & 0.2 & 0.21 \\
\hline \multicolumn{6}{|l|}{ Females, $\mathrm{n}=18$} \\
\hline skin length, cm & $71^{\mathrm{b}}$ & $74^{\mathrm{a}}$ & $73^{\mathrm{a}}$ & 0.6 & 0.01 \\
\hline skin weight, $g$ & $110^{\mathrm{b}}$ & $127^{\mathrm{a}}$ & $133^{\mathrm{a}}$ & 6.1 & 0.009 \\
\hline colour & 5.8 & 6.2 & 5.5 & 0.3 & 0.47 \\
\hline purity & 3.1 & 3.0 & 2.8 & 0.2 & 0.67 \\
\hline density guard hairs & 5.6 & 5.5 & 5.7 & 0.2 & 0.91 \\
\hline density under-fur & 5.6 & 5.5 & 5.8 & 0.3 & 0.93 \\
\hline hair quality & 5.5 & 5.5 & 5.3 & 0.3 & 0.83 \\
\hline guard hair length, mm & $22.4^{\mathrm{a}}$ & $22.8^{\mathrm{a}}$ & $19.2^{\mathrm{b}}$ & 0.3 & 0.001 \\
\hline under-fur length, mm & $14.5^{\mathrm{a}}$ & $15.0^{\mathrm{a}}$ & $12.9^{\mathrm{b}}$ & 0.2 & 0.001 \\
\hline total impression & 5.6 & 5.7 & 5.8 & 0.3 & 0.91 \\
\hline
\end{tabular}

different letters within diet denote significant differences $(\mathrm{P}<0.05)$

significantly higher at 28 weeks than at 18 weeks. The uric acid excretion was not affected by diet, but excretion levels were lower at 28 weeks than at 18 weeks. Total xanthine excretion declined with increasing dietary BPM, and animals fed the $8 \%$ BPM diet excreted significantly less than the control animals. The urinary concentration of hypoxanthine was lowest among the control animals, but there was no significant effect of diet on total daily excretion of hypoxanthine. The 28 weeks old animals excreted less xanthine and hypoxanthine, as compared with the 
18 weeks old animals. Creatinine excretion was not significantly influenced by diet or age, but there was a tendency for reduced urinary concentration and daily excretion of creatinine with dietary BPM inclusion.

\section{Skin and fur characteristics}

Dietary treatment did not affect length and weight of male skins, but female skins from animals fed 4 and 8\% BPM were longer and heavier than skins from the control animals (Table 6). The fur quality characteristics revealed that guard hairs and underfur were significantly shorter among skins of both male and female animals fed 8\% BPM, compared with the controls and animals fed 4\% BPM (Table 6). Other fur parameters, including total impression, were unaffected by dietary replacement of fish meal with BPM.

\section{DISCUSSION}

The growth performance in the present study was satisfactory with animals reaching higher body weights than usually obtained in mink production (Hansen et al., 1991). The feed conversion rate (kJ ME/g BW gain) recorded on group basis did not differ among diets (Table 2), indicating that the lower body gain and final body weights observed among males fed 8\% BPM were caused by lower feed intake than in the other groups during the early phase of the experiment. Also female gain was lower during the two first months of feeding 8\% BPM, but unlike the males this was fully compensated for during the remaining part of the growth period. The mink is a strict carnivore, which often responds to dietary changes with temporarily reduced feed intake. This sensitivity to dietary changes is most likely related to palatability and is most evident for ingredients of vegetable origin (Skrede and Cheeke, 2005). Furthermore, in the present study the experimental diets were presented to the animals about one week after weaning, when the digestive functions are not fully developed (Elnif and Enggaard Hansen, 1988). A gradual adjustment of dietary BPM would have given a smoother adaptation, which may have contributed to a higher feed intake for the BPM diets during the first half of the experiment. A previous study with BPM in a dry diet for blue foxes (Alopex lagopus), a facultative carnivore, showed improved gain and feed conversion rates when using $12 \%$ BPM, accounting for $30 \%$ of dietary protein (Skrede and Ahlstrøm, 2002). The more pronounced lower body weight gain in males than in females fed the $8 \%$ BPM diet, indicates that the early suboptimal energy intake, probably as a result of poor palatability, affected the more rapidly growing males to a greater extent than the females. 


\section{Balance experiments}

In the present study, replacing fish meal with BPM had no effect on $\mathrm{N}$ digestibility. This finding is in accordance with Øverland et al. (2006), but differs from results obtained by Hellwing et al. (2005), where inclusion of BPM reduced digestibility in mink, especially in young animals. Also Skrede et al. (1998) reported that the $\mathrm{N}$ digestibility of BPM was lower than common values for high-quality fish meal, indicating that different batches of BPM may have different $\mathrm{N}$ digestibility. Hellwing et al. (2005) found that reduced urinary excretion of $\mathrm{N}$ with increasing inclusion of BPM compensated for the increased faecal excretion, resulting in N-balance being unaffected, and concluded that BPM could be fed at levels up to $40 \%$ of digestible $\mathrm{N}$ without affecting protein metabolism. The present study supported the findings of Hellwing et al. (2005) that increasing level of dietary BPM reduced urinary N excretion, and that BPM had minor and non-significant effects on $\mathrm{N}$ retention. This indicates that the additional nucleic acids provided by BPM might be utilized in vivo.

The retained $\mathrm{N}$ at 18 weeks of age in the present study accounted for $21-26 \%$ of the digested N, which is similar to values obtained by Hellwing et al. (2005) in animals of the same age. The lower levels of retained $\mathrm{N}$ at 28 weeks than at 18 weeks would be expected due to declining protein synthesis for body growth, although protein synthesis for hair growth is very active at this age.

Fat digestibility was significantly reduced with increasing inclusion of BPM in the present study. Similar effects have been reported in another study with mink (Hellwing et al., 2005), and in Atlantic salmon (Storebakken et al., 2004; Berge et al., 2005).

\section{Urinary excretion of purine derivatives}

In the present study, the urine excretion was lowest for the $8 \%$ BPM diet, which might be due to a lower intake of dietary water or drinking water. Reutilization of purines and pyrimidines takes place in muscle, liver and gut tissue, probably as a result of the high turnover of RNA in these tissues (D'Mello, 1982). Dietary free purines (hypoxanthine, guanine and adenine) can be reconverted to their corresponding nucleotides (IMP, GMP and AMP respectively (Zöllner, 1982; Natsumeda et al., 1989), and experiments in both laying hens and mice have shown that large quantities of dietary pyrimidine nucleosides can be incorporated into hepatic nucleic acids (Berthold et al., 1995). Thus, an important effect of dietary purines and pyrimidines is that de novo synthesis can be reduced. Although fish meal contains less nucleic acids than single-cell protein meals (Devresse, 2000), the animals receiving the $8 \% \mathrm{BPM}$ diet ingested only approximately $0.4 \mathrm{~g}$ more nucleobases daily, as compared with the animals receiving the control diet. The 
excretion of purine metabolites was not consistent with the dietary level of BPM, on the contrary, for allantoin the level was higher for the control than for the BPM groups. The reason for this is not clear, but the complex metabolism of nucleotides including both recycling and reduction of de novo synthesis during abundance may have evened out the level of excretion among the groups.

The dominating purine metabolite in urine was allantoin (97-99\%), which is reasonable because it is the end product of nucleotide catabolism (D'Mello, 1982). The excretion of its precursors uric acid, xanthine and hypoxanthine accounted for only $1-3 \%$ of the total excretion. These values are in line with those recorded by Tauson et al. (1997). In their study distributions of purine derivates in mink urine were found to be $97 \%$ from allantoin, $2.5 \%$ from uric acid and $1.0 \%$ from xanthine and hypoxanthine.

Effects of dietary purines have been demonstrated in rats when fed free adenine at $30 \mathrm{mmol} / \mathrm{kg}$ diet (Brulé et al., 1988). Free adenine caused less weight gain, greater kidney weight, greater urine excretion and nephropathy, while urinary levels of allantoin, uric acid and creatinine were reduced. When feeding adenine as nucleoside or nucleotide, no difference from the control was observed, but urinary excretion of allantoin was increased. The study concluded that among the purine bases and their nucleotides and nucleosides, free adenine was the only nucleic acid compound that could produce adverse effects in rats. The diets of our study did not include free adenine, but only nucleotides and nucleosides of various purines and pyrimidines in the BPM. Thus, the moderate effect and lack of effect of diet on the urinary excretion of the purine base derivatives in the present study indicated that mink similarly to rats (Brulé et al., 1988), could metabolize the supplied nucleotides.

\section{Skin and fur parameters}

The reduction in length of guard hairs and under-fur as a result of feeding $8 \%$ BPM cannot be readily explained by replacing fish meal protein with the BPM. However, methionine is likely to be the first limiting amino acid in mink diets (Børsting and Clausen, 1996) and cysteine is the dominating amino acid in fur. Previous studies with mink have shown a rather poor digestibility of the cysteine in BPM (Skrede et al., 1998). Although the protein level in the present study was within the requirement of $30-35 \%$ of ME indicated by NRC (1982) for mink kits after 13 weeks of age, and above the minimum requirement of $30 \%$ of ME recommended by Hansen et al. (1991), we cannot exclude the possibility that suboptimal levels of sulphur-containing amino acids may have limited hair growth in animals fed the highest level of BPM.

Considering the fact that other criteria of fur quality than hair length, including general impression, were unaffected by treatment, the present study indicated 
that the BPM fed at up to $40 \%$ of digestible protein when replacing fish meal, supported similar fur quality as the fish meal based control diet.

\section{CONCLUSIONS}

Partial replacement of fish meal with BPM in diets for growing mink resulted in only minor changes in nutrient digestibility, except for reduced fat digestibility. Increasing BPM did not influence N-metabolism, and reduced urinary excretion of allantoin and xanthine, but not uric acid and hypoxanthine. BPM could account for $40 \%$ of dietary protein in growing-furring mink without negative effects on body weight gain or fur growth. However, replacement of fish meal with BPM may reduce feed intake and body weight gain temporarily in young kits, thus gradual inclusion of dietary BPM is recommended.

\section{REFERENCES}

Berge G.M., Baeverfjord G., Skrede A., Storebakken T., 2005. Bacterial protein grown on natural gas as protein source in diets for Atlantic salmon, Salmo salar, in saltwater. Aquaculture 244, 233-240

Berthold H.K., Crain P.F., Gouni I., Reeds P.J., Klein P.D., 1995. Evidence for incorporation of intact dietary pyrimidine (but not purine) nucleosides into hepatic RNA. Proc. Nat. Acad. Sci. USA 92, 10123-10127

Børsting C.F., Clausen T.N., 1996. Requirements of essential amino acids for mink in the growingfurring period. Proceedings of VIth International Science Congress Fur Animal Production. Applied Science Reports 28, Polish Society of Animal Production, Warsaw (Poland), pp. 15-24

Brulé D., Sarwar G., Savoie L., Campbell J., Van Zeggelaar M., 1988. Differences in uricogenic effects of dietary purine bases, nucleosides and nucletides in rats. J. Nutr. 118, 781-786

Devresse B., 2000. Nucleotides - a key nutrient for the immune system of shrimp? Feed Mix 8, 20-22

D'Mello J.P.F., 1982. Utilization of dietary purines and pyrimidines by non-ruminant animals. Proc. Nutr. Soc. 41, 301-308

EC, 1971a. First commission directive 71/250/EEC of 15 June 1971 establishing Community Methods of Analysis for the Official Control of Feedingstuffs. Official Journal L 155, 12.7.1971, 13-37

EC, 1971b. Second commission directive 71/393/EEC of 18 November 1971 establishing Community Methods of Analysis for the Official Control of Feedingstuffs. Official Journal L 279, 20.12.1971, 7-18

EC, 1993. Commission Directive 93/28/EEC of 4 June 1993 amending Annex I to the third Directive 72/199/EEC establishing Community Methods of Analysis for the Official Control of Feedingstuffs. Official Journal L 179, 22.7.1993, 8-10

EC, 1998. Commission Directive 98/64/EC of 3 September 1998 establishing Community Methods of Analysis for the Determination of Amino-Acids, Crude Oils and Fats, and Olaquindox in Feedingstuffs. Official Journal L 257, 19.9.1998, 14-28

Elnif J., Enggaard Hansen N., 1988. Production of digestive enzymes in mink kits. Biology, pathology and genetics of fur bearing animals. Proceedings of 4th International Science. Congress Fur Animals Production, Toronto (Canada), pp. 320-326 
Hansen N.E., Finne L., Skrede A., Tauson A.-H., 1991. Energy supply in mink and foxes (in Danish). DSR Forlag, Copenhagen (Denmark), pp. 59

Hellwing A.L.F., Tauson A.-H., Ahlstrøm Ø., Skrede A., 2005. Nitrogen and energy balance in growing mink (Mustela vison) fed different levels of bacterial protein meal produced on natural gas. Arch. Anim. Nutr. 59, 335-352

Jørgensen G., Glem-Hansen N., 1973. A cage designed for metabolism and nitrogen balance trials with mink. Acta Agr. Scand. 23, 3-4

Mc Cleary B.V., Solah V., Gibson T.S., 1984. Quantitative measurement of total starch in cereal flours and products. J. Cereal Sci. 20, 51-58

Natsumeda Y., Ikegami T., Olah E., Weber G., 1989. Significance of purine salvage in circumventing the action of antimetabolites in rat hepatoma cells. Cancer Res. 49, 88-92

NRC, 1982. Nutrient Requirements of Mink and Foxes. $2^{\text {nd }}$ revised Edition. National Academy Press. Washington, DC

Øverland M., Kjos N.P., Skrede A., 2004. Effect of bacterial protein meal grown on natural gas on growth performance and carcass traits of pigs. Italian J. Anim. Sci. 3, 323-336

Øverland M., Romarheim O.H., Hovin M., Storebakken T., Skrede A., 2006. Apparent total tract digestibility of unprocessed and extruded diets containing basic and autolyzed bacterial protein meal grown on natural gas in mink and rainbow trout. Anim. Feed Sci. Tech. (in press)

Øverland M., Skrede A., Matre T., 2001. Bacterial protein grown on natural gas as feed for pigs. Acta Agr. Scand., Sect. A, Anim. Sci. 51, 97-106

Reiten J., 1977. Studies on light regulation in mink (in Norwegian). Scientific Reports of Agricultural University of Norway, 55 (24), pp. 24

SAS, 2002. SAS Version 8.2. SAS Institute Inc., Cary, NC

Skrede A., 1976. Studies on alternative protein sources for mink (in Danish). Dansk Pelsdyravl 39, 224-227

Skrede A., Ahlstrøm Ø., 2002. Bacterial protein produced on natural gas: a new potential feed ingredient for dogs evaluated using the blue fox as a model. J. Nutr. 132, 1668S-1669S

Skrede A., Berge G,M., Storebakken T., Herstad O., Aarstad K.G., Sundstøl F., 1998. Digestibility of bacterial protein grown on natural gas in mink, pigs, chicken and Atlantic salmon. Anim. Feed Sci. Tech. 76, 103-116

Skrede A., Cheeke P.R., 2005. Feeding and nutrition of fur-bearing animals. In: Applied Animal Nutrition. Feeds and Feeding. Pearson - Prentice Hall, New Jersey, (USA), pp. 514-522

Skrede A., Schøyen H.F., Svihus B., Storebakken T., 2003. The effect of bacterial protein grown on natural gas on growth performance and sensory quality of broiler chickens. Can. J. Anim. Sci. $83,229-237$

Storebakken T., Baeverfjord G., Skrede A., Olli J.J., Berge G.M., 2004. Bacterial protein meal in diets for Atlantic salmon, Salmo salar, in freshwater. Aquaculture 241, 413-425

Tauson A.H., Elnif J., Wamberg S., 1997. Nitrogen balance in adult female mink (Mustela vison) in response to normale feeding and short-term fasting. Brit. J. Nutr. 78, 83-93

Thode S., 1999. Determination of purine derivatives (allantoin, uric acid, hypoxanthine, xanthine) and creatinine in cattle urine by use of HPCL (in Danish). Internal Report No. 127. Danish Institute of Agricultural Sciences, pp. 8

Zöllner N., 1982. Purine and pyrimidine metabolism. Proc. Nutr. Soc. 41, 329-341 